И существует вероятность, что в недалеком будущем уже мужчины станут бороться за уравнение в социальных возможностях.

Список литературы:

1. Здравомыслова О.М. Представление о гендере связано с осознанием личности / О.М. Здравомыслова, Н. Кагай // Университет Каггари - Горбачев - Фонд,ИСЭПН РАН. - М., 2005. - С. 56 - 59.

2. Исакова Е.В. Влияние гендерных стереотипов на трудовую деятельность / Е.В. Исакова - М.: ГУ ВШЭ, МАКС Пресс, 2007. -С. 198-212.

3. Батлер Дж. Случайно сложившиеся основания: феминизм и вопрос о «постмодернизме» //Введение в тендерные исследования. Ч. ІІ: Хрестоматия. -Харьков: ХЦГИ, 2001; СПб.: Алетейя, 2001. С. 235-258.

4. Брандт Г. Феминизм и российское сознание //Феминистская теория и практика: Восток-Запад: Материалы международной научно-практической конференции. СПб., 1996. - C. 71-72.

\title{
Профессиональная компетентность педагога как средство обеспечения защиты прав детей от семейного насилия в условиях ДОО
}

Руфова Ю.С., студентка, Вилюйский педагогический колледж имени Н.Г. Чернышевского, 2. Вилюйск

Научный руководитель: к.n.н. Борисова 3.H. E-mail: vpc_proekt@mail.ru

По СМИ все чаще и чаще передают новости о самых разных нарушениях прав детей. Последние новости: учащение педофилии, смерть детей от обморожения и переохлаждения и т.д. Следовательно, необходимо активизировать работу педагогов по защите прав детей от семейного насилия.

Гипотеза: Защита детей от семейного насилия будет обеспечена, если деятельность воспитателя детского сада по данной проблеме будет профессионально компетентной.

Объект нашего исследования - защита прав детей от семейного насилия, а предмет - изучения является деятельность педагога, его компетенция по изучаемой проблеме.

Цель работь - изучить и оценить содержание профессиональной компетентности педагогов в обеспечении защиты прав детей от семейного насилия.

На 1 этапе изучены методом педагогического анализа психолого-педагогические и социальные аспекты обеспечения защиты прав детей педагогами детского сада. Нами изучены труды Э.Ф. Зеер, Л.В. Лавриненко, Д. Карнеги и других. Ими установлено, что именно в период дошкольного детства у всех детей, живущих в поликультурном пространстве происходит обезличенное формирование личности, ведущей к нарушению этнического самосознания. По мнению большинства исследователей, этническая идентификация должна начинаться с малых лет, при этом уважительное отношение к 
представителям других этносов будет сформировано, если он также имеет четкое представление об их культуре, языке и образе жизни. Лучшим условием для развития этнического самосознания является народное творчество, его внедрение в игровую деятельность детей.

2 этап - практическое исследование. Мы проводили практическое исследование в одном из ДОУ г. Вилюйска. В течение трех дней провели диагностирование эмоциональной окрашенности настроения детей во время утреннего приема. Цель: в каком настроении дети приходят из дома в садик, каковы причины плохого настроения? Для этого мы использовали модифицированный тест Люшера. В исследовании участвовало 18 детей 6-ти лет. Выяснилось, что 21\% детей приходят в садик в плохом настроении. При беседе выяснилось, что родители детей чаще ругают, некоторые наказывают, есть дети, которые жалуются на то, что у них нет игрушек, книжек. Один мальчик говорит, что утром он хочет дома покушать, а мама говорит ему, что нет еды. 7 детей при беседе говорили, что их дома физически наказывают. Преимущественно детей бьют матери. Поскольку дети уже большие, многие не хотят, чтобы чужие люди знали о нехорошем поведении их родителей. Мальчик Дима, который попал в приют из-за запоя родителей, рассказывает, что родители уехали в деревню, поэтому он находится в детском приюте.

А также провели беседу с воспитателями с целью выяснения социального благополучия детей. Мы узнали, что в каждой группе есть родители, у которых наблюдается различные проблемы по социальной защищенности детей. Основные проблемы следующие:

1. Алкоголизм одного из родителей (реже обоих родителей).

2. Ненадлежащий уход за детьми - выражается в том, что некоторых детей родители «забывают» в детском саду, или вовсе не приводят в детский сад. Некоторые родители не следят за детьми, за их здоровьем. Дети в садик приходят грязными, не умытыми, не причесанными.

3. Есть родители, которые не обеспечивают нормальное питание у детей (безработность, состояние запоя и др.).

4. Больше всего наблюдается психологическое насилие над детьми.

Изучив теоретические основы необходимости овладения воспитателями специальной компетентности педагогов ДОУ по обеспечению защиты детей от семейного насилия, а также проводив практическое исследование, мы приходим к следующему выводу:

1. Основными формами работы с родителями, имеющими проблемы в воспитании своих детей, являются индивидуальная беседа, посещение детей на дому, при острой необходимости обращение в органы социальной защиты детей.

2. K средствам такой работы относятся педагогическое общение, информационные материалы, например папки-передвижки, выступление специалистов на родительском собрании и др.

3. Распространенными методами педагоги называют беседу, доклад, специальную информацию и др.

В заключении можно сказать о том, что необходимо активизировать работу не только над повышением специальной компетентности педагогов. Самое важное необходимо обеспечить соблюдение защиты ребенка на счастливое детство. Для этого овладеть профессиональной компетентностью: активизировать, совершенствовать работу с родителями, нарушающими права своих детей. 


\title{
Список литературы:
}

1. Закон РФ «Об образовании»

2. Международная конвенция прав ребенка

3. Порядок организации и осуществления общего образования (дошкольного образования).

4. Выготский Л.С. Педагогическая психология /Под ред. В. В. Давыдова. - М.: ИЦ «Академия», 2001. - 480с.

5. Дошкольная педагогика с основами методик воспитания и обучения: Учебник для вузов. Стандарт третьего поколения / под ред. А.Г.Гогоберидзе, О.В.Солнцевой. СПб.: Питер, 2014. - 464c.

6. Зеер Э.Ф. Психология личностно-ориентированного профессионального образования. - Екатеринбург: Изд-во Урал. проф.-пед. ун-та, 2007. - 372 с.

7. Немов Р.С. Практическая психология. -М.: ИЦ «Академия», 1999. -320с.

\section{Формирование этно-экологических представлений младших школьников посредством фольклора народов Якутии}

\author{
Солодухина П., Фильченко А., учащиеся, \\ МОУ Гимназия №1, г. Нерюнгри
}

\section{Научный руководитель: учитель КНРС(Я) Филинова Е.Б. E-mail: d-orm-elena2013@yandex.ru}

Этно-экология - важнейшая часть современной экологии. Она изучает традиции народов мира по отношению к природе, а также особенности бережного использования природы. Такое отношение характерно для представителей народов, живущих вне цивилизации. Основы заботливого отношения к природе у представителей коренных народов формируются в раннем детстве из сказок и рассказов старшего поколения.

Представления о своей малой родине, ее традициях играют важную роль в становлении каждого человека. Понятие «Родина» всегда связано с национальной культурой. Все народы мира используют фольклор в формировании первых этноэкологических представлений у детей. Это подтверждается наличием в фольклоре всех народов сказок, в интересной форме объясняющих происхождение окраса, формы тела у различных животных. Можно сказать, что этно-экологическое содержание фольклора обеспечивает эффективность процесса формирования культурного человека, уважающего свой народ.

Развитие этно-экологических представлений очень актуально для каждого ребенка. Зачастую именно в этом он находит воплощение своих самых главных интересов, обретает своё "Я" в пространстве родной ему культуры.

Экологические представления детей младшего школьного возраста еще несовершенны. Часто городские дети младшего школьного возраста могут точно перечислить наиболее известных животных региона, где проживают, но не всегда могут точно описать их внешний вид, не знают о повадках и способах питания. А вот мелкие животные, грызуны, рыбы, птицы, не всегда входят в сферу их познания. Нечасто они знакомы со сказками разных народов о происхождении окраса или образа жизни животных и птиц. Младшие школьники также имеют довольно ограниченные 